\title{
Fall armyworm, Spodoptera frugiperda (Lepidoptera, Noctuidae): State of knowledge and control methods
}

\author{
Abissi Marc ADJAOKE ${ }^{1 *}$, Appolinaire ADANDONON ${ }^{2}$ and Ghislain TEPA YOTTO ${ }^{2}$ \\ ${ }^{1}$ Ecole Doctorale des Sciences Agronomiques et de l'EAU (EDSAE), Université Nationale d'Agriculture (UNA), BP 43, \\ Kétou, Benin. \\ ${ }^{2}$ Laboratoire des Sciences Végétales Horticoles et Forestières, Ecole de Gestion et de Production Végétale et \\ Semencière (EGPVS), Université Nationale d'Agriculture (UNA), BP 43, Kétou, Benin.
}

Received 11 June, 2021; Accepted 3 August, 2021

\begin{abstract}
The objective of this article is to review the knowledge on Spodoptera frugiperda and the possible management strategies against the pest to identify research areas for its integrated management. A review of the literature shows that $S$. frugiperda (Lepidoptera: Noctuidae) has been causing considerable damage to maize and many other crops since its detection in several African countries and it is one of the most destructive pests to have entered Africa in the 21st century. Several control methods have been developed against this pest ranging from the use of synthetic plant protection products to agroecological and biological controls. The biology, distribution and control methods of the pest are well documented. However, Integrated Management of the pest remains a major challenge; the main control is chemical. Innovative research on biological and ecological control methods will help to overcome the constraints and promote sustainable management of the pest. Very few scientifically proven alternatives adapted to the African context exist. This gap needs to be filled by further research considering aspects such as the inventory of local natural enemies, the performance of key parasitoids and the potential of local entomopathogens for sustainable and integrated management of the pest.
\end{abstract}

Key words: Spodoptera frugiperda, natural enemies, integrated management.

\section{INTRODUCTION}

Spodoptera frugiperda (Lepidoptera: Noctuidae) is a lepidopteran pest, native to the Americas, attacking more than 80 species of crops and has found its way to Africa causing much economic damage to crops especially maize (Prasanna et al., 2019). Tens of millions of smallholder farmers in Africa are affected by the pest as its host plants including Poaceae (maize, sorghum and millet) are all staple crops in Africa (Day et al., 2017). Spodoptera frugiperda is therefore a major threat to food security and a serious problem from an economic and environmental perspective (Tambo et al., 2017). Since the invasion by the pest, much investment has been made in synthetic chemicals which use remains the main recourse of farmers (Kumela et al., 2018). Other

*C orrespond ing a uthor. E-mail: marc.adja oke@gmail.com. Tel: +229 97290611.

Author(s) agree that this article remain permanently open access under the terms of the Creative Commons Attribution License 4.0 Intemational License 
sustainable methods represent better alternative for vulnerable producers with limited resources (Thierfelder et al., 2018). However, little recommendable empirical evidence is available for effective and more sustainable management of the pest in Africa, as most of the existing information is based on studies in the Americas (Baudron et al., 2019). This article reviews the state of knowledge on the fall armyworm and also takes stock of some of the pest control work conducted around the world to serve as a crucible of systematised information and to draw probable avenues of research for a more integrated management of the pest in Africa.

\section{METHODOLOGY}

For this review, the search engines Google Scholar, ScienceDirect and the Electronic Scientific Information Base (AGORA) were consulted. Literature searches were carried out by entering key words and phrases in the aforementioned search engines. Several keywords or topical statements have been used in this context (Table 1). This first step allowed the identification of a very wide range of documents which were thereafter summarized and analyzed following a systematic sorting. The titles and/or abstracts of the works were examined to eliminate those that did not fit precisely with the objective of the study. This sorting made it possible to retain 300 relevant documents including scientific articles, master's theses, doctoral theses, conference proceedings, book chapters on the theme and others published until March 2021. Our documentary research also led us to the libraries of Benin universities and other specialized institutions at the national, regional and international levels. All the documents selected were then subject to in-depth analysis and extraction of data used in this review.

\section{Origin and distribution}

Spodoptera frugiperdais native to tropical and subtropical regions of the Western Hemisphere of America, from the United States to Argentina (Cokola, 2019). It is commonly found in the Caribbean, including Puerto Rico (Capinera, 2001). In 2016, S. frugiperda was reported for the first time in West Africa (Cock et al., 2017; Goergen et al., 2016). By the end of 2017, the pest had spread to more than 30 countries across tropical and southern Africa as well as Madagascar, Seychelles, and Cape Verde with definite potential to spread to parts of the Mediterranean Asia and Australia (Day et al., 2017). Through the use of an environmental suitability index, the distribution of $S$. frugiperda has been modeled across the African continent (Figure 1) and currently over 44 countries are affected in sub-Saharan Africa (Day et al., 2017). S. frugiperda has also been reported in Asia, specifically in India since 2018 (Shylesha et al., 2018; Kalleshwaraswamy et al., 2018).

\section{Description and biology}

Insects belonging to the order Lepidoptera are those with complete metamorphosis with variable cycles including 4 stages namely egg, larvae, pupa and adult (Cokola, 2018). For S. frugiperda, the complete cycle is on average 30 days when conditions are dry $\left(25 \pm 1^{\circ} \mathrm{C}\right.$ and $70 \pm 10 \%$ relative humidity), and favorable for its growth and development (Busato et al., 2005). However, this cycle can extend to 60 days in spring and autumn and 80 to 90 days in winter without diapause (Capinera, 2014; Prasanna et al., 2018).

\section{Egg stages}

The egg of $S$. frugiperda is dome-shaped with a flattened base, curving upwards to a strongly rounded point at the top (Prasanna et al., 2018). It measures about $0.4 \mathrm{~mm}$ in diameter and $0.3 \mathrm{~mm}$ in height (Luginbill, 1928; Capinera, 2014). The fecundity per life cycle of a female S. frugiperda ranges from 1500-2000 (Prasanna et al., 2018). Females may or may not cover the laid eggs with fluffy material or self-silks to protect them (Hardke et al., 2015; Du Plessis et al., 2018). The number of eggs per mass varies between 150 and 200 with an egg stage duration ranging from 2 to 3 days during the hot summer months (Prasanna et al., 2018). Eggs may be cream, green or brown, but turn black after development of an embryo (Capinera, 2001). The different stages of the development cycle of $S$. frugiperda are illustrated in Figure 2.

\section{Larval stage}

S. frugiperda has six larval instars from hatching and the appearance as neonates, lasting 14 days during warm summer months and 30 days during the period of low temperature (Prasanna et al., 2018). The duration of the larval stage is influenced by a combination of factors including temperature and feeding (Hardke et al., 2015). The width of the head capsules varies from about 0.35 to $2.6 \mathrm{~mm}$ respectively for instars one to six with a size reaching about 1.7 to $34.2 \mathrm{~mm}$ during the six successive instars (Capinera, 2001). The raised spots, usually dark coloured with spines, are observed dorsally on the body of the mature larva (Visser, 2017; Prasanna et al., 2018). It is also possible to find two colours (orange and black) on the head from the third larval instar onwards (Capinera, 2002). This variation in colours at the last three larval instars is a function of diet and other factors (Hardke et al., 2015). In the terminal stage, the larval epidermis is rough or granular in texture when examined closely (Kalleshwaraswamy et al., 2018). At this stage, S. frugiperda larvae can be identified by some characteristic features (Figure 3 ) namely four large spots arranged in a square on the upper surface on the eighth abdominal segment and a white inverted " $Y$ " mark on the head (Prasanna et al., 2018).

\section{Pupal stage}

The pupal stage of $S$. frugiperda is often found in shaded, hidden areas or in leaf debris and soil at a depth of $2-8 \mathrm{~cm}$ (Luginbill, 1928; Capinera, 2001). The cocoon is reddish-brown in colour and 14-18 $\mathrm{mm}$ long and about $4.5 \mathrm{~mm}$ wide (Capinera, 2001). The duration of this stage is strongly influenced by temperature and is about 8-9 days during summer, but could extend to 20-30 days during cold periods (Prasanna et al., 2018). In S. frugiperda, diapause is not observed at this stage as in many species belonging to the same order (Luginbill, 1928). At the cocoon level, it is possible to distinguish between males and females from the distance between the genital opening and the anal slit; this distance being greater in females than in males (Luginbill, 1928; Kalleshwaraswamy et al., 2018).

\section{Adult insect}

Adults of S. frugiperda are nocturnal, most active during warm and humid evenings with an estimated lifespan of about 10 days on average or about 7 to 21 days (Prasanna et al., 2018). They measure between 32 and $40 \mathrm{~mm}$ with remarkable morphological differences between the sexes (Capinera, 2001). In males, the forewing is shaded, usually grey and brown, with white triangular spots at the apical area near the centre of the wing (Figure 4), while 
Table 1. Keywords used for online documentary research.

\begin{tabular}{ll}
\hline Pests I predators or natural enemies & Pest managements \\
\hline Spodoptera frugiperda, & integrated management + Spodoptera frugiperda \\
Natural enemies + Spodoptera frugiperda & Entomopathogens + Spodoptera frugiperda \\
predators + Spodoptera frugiperda & Metarhizium + Spodoptera frugiperda \\
Cotesia marginiventris + Spodoptera frugiperda & Biological controls + Spodoptera frugiperda \\
parasitoids + Spodoptera frugiperda & Nuclear Polyhedrosis Virus + Spodoptera frugiperda \\
Chelonus insularis + Spodoptera frugiperda & Beauveria + Spodoptera frugiperda \\
Telenomus remus + Spodoptera frugiperda & Ecological controls + Spodoptera frugiperda \\
Trichogramma sp. + Spodoptera frugiperda & Cultural controls + Spodoptera frugiperda \\
& Varietal controls + Spodoptera frugiperda \\
\hline
\end{tabular}

Source: Adjaoke (2021).
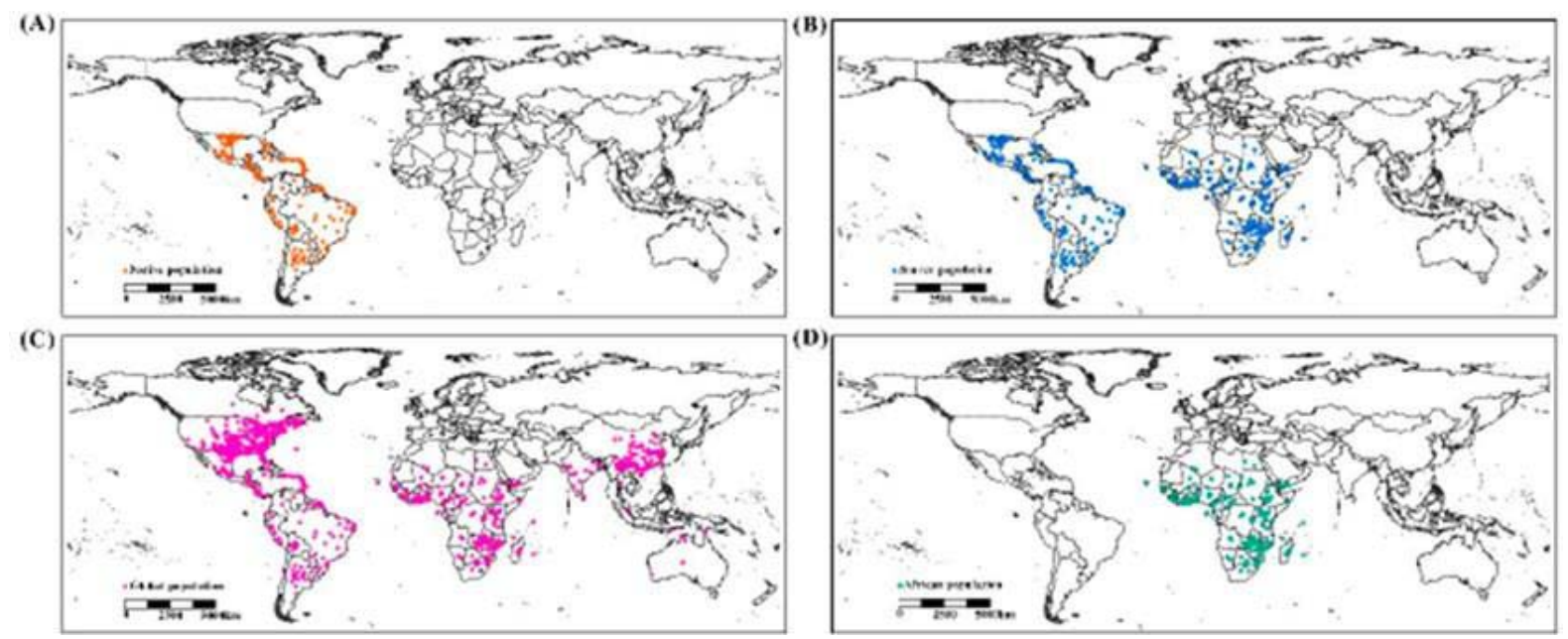

Figure 1. Geographical distribution of Spodoptera frugiperda. (A) original population, (B) origin of the population, (C) global population and (D) African population.

Source: Fan et al. (2020)

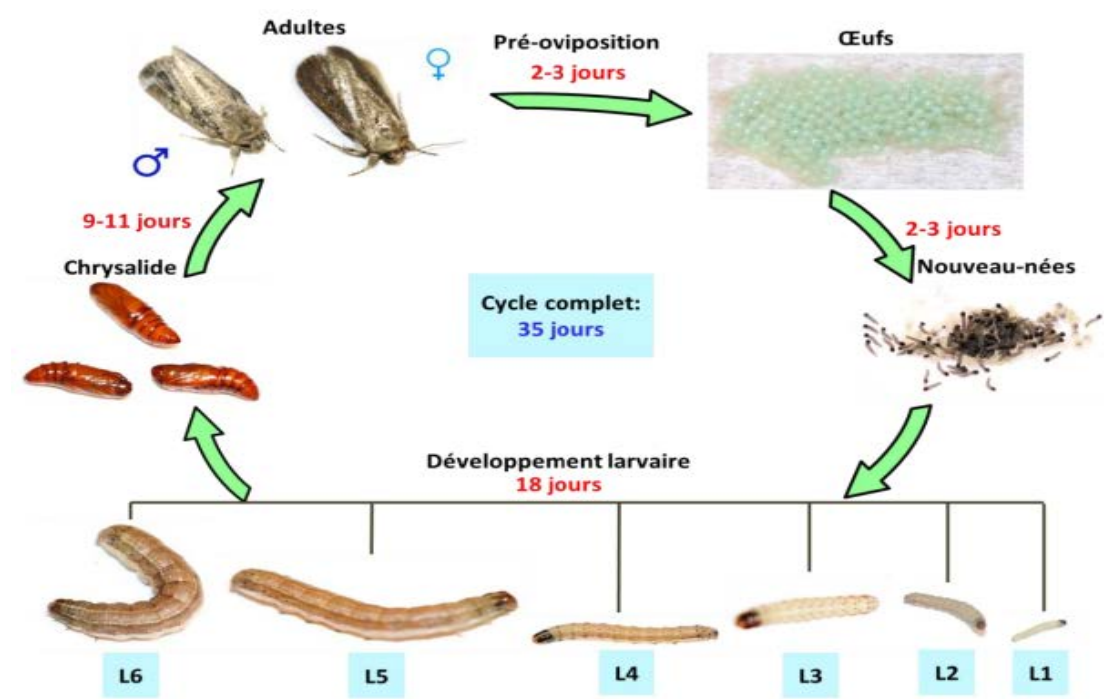

Figure 2. Development cycle of Spodoptera frugiperda. Source: Cokola (2018). 


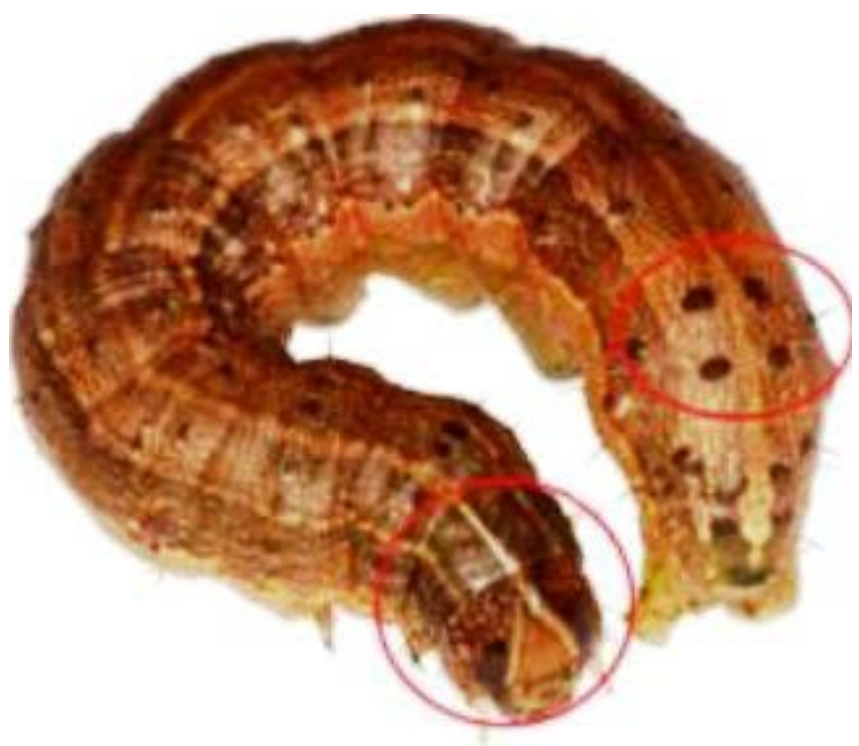

Figure 3. Characteristic marks of the adult larva of Spodoptera frugiperda.

Source: Visser (2017).
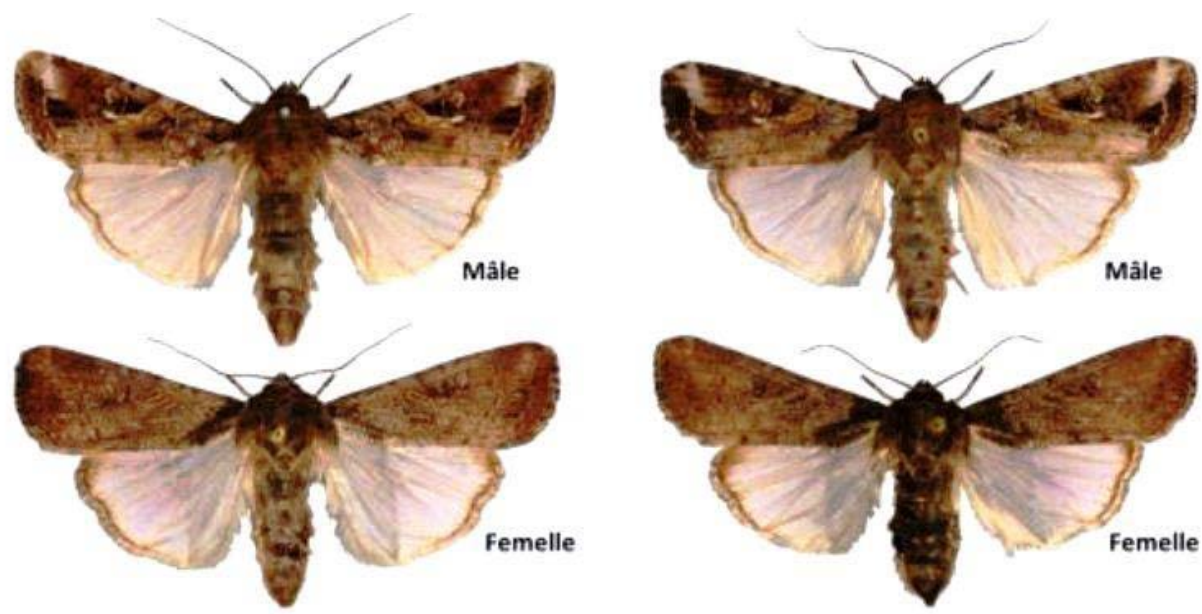

Figure 4.Patterns of wing variation in adult Spodoptera frugiperda.

Source: (Visser, 2017)

in females this characteristic feature is less marked, ranging from a uniform greyish brown to a fine mottling of grey and brown (Hardke et al., 2015; Shylesha et al., 2018). The hindwing is silvery-white with a narrow, dark margin in males (Figure 4) as well as in females (Kalleshwaraswamy et al., 2018). In general, adults of S. frugiperda feed mainly on nectar of various plants and are active for short period before sunset and during the night (Luginbill, 1928). In nature, they remain hidden under foliage and in whorls (Capinera, 2001; Visser, 2017). After 3-4 days of pre-oviposition period, the female lays most of her eggs during the first 4-5 days of her life, but with extreme cases for up to 3 weeks (Prasanna et al., 2018). A female can lay 6-10 masses of 100-300 eggs. This performance is significantly limited under laboratory conditions (Prasanna et al., 2018). Two factors that influence the longevity of adults: are feeding and temperature (Luginbill, 1928). In the laboratory, the total duration of the development cycle of $S$. frugiperda was about $39 \pm 5$ days (Kouakou et al., 2019). This duration was almost identical to that obtained by Schmidt-Durán et al. (2015). Indeed, these authors observed during their work that under environmental conditions marked by a temperature of $24^{\circ} \mathrm{C}, 70 \%$ relative humidity and artificial feeding, the complete life cycle of $\mathrm{S}$. frugiperda is 38 days. Under the same conditions, the larval and chrysalis stages lasted $24 \pm 5$ days and $9 \pm 1$ day respectively, while from oviposition to hatching, the egg takes about 2 to 3 days ( $2.75 \pm 44$ days). To each developmental stage, corresponds a specific life span, weight and size (Table 2) in the pest (Cokola, 2018). Da Sylva et al. (2016) obtained a larval life span ranging from $21.41 \pm 0.15$ to $29.37 \pm 0.5$ days and a chrysalis stage duration oscillating between $8.54 \pm 0.09$ and $9.70 \pm 0.20$ days with different food supports.

Some confusion arises in the morphological identification of adult 
Table 2. Characteristics of the developmental stages of Spodoptera frugiperda

\begin{tabular}{lccc}
\hline Instar & Duration (day) & Weight $(\mathbf{m g})$ & Size $(\mathbf{m m})$ \\
\hline Egg & $2.72 \pm 0.46$ & - & - \\
First larval instar & $3.55 \pm 0.51$ & $0.64 \pm 0.18$ & $3.0 \pm 0.0$ \\
second larval instar & $1.39 \pm 0.50$ & $3.02 \pm 0.88$ & $5.2 \pm 0.4$ \\
Third larval instar & $1.55 \pm 0.51$ & $13.7 \pm 2.39$ & $9.2 \pm 0.8$ \\
Fourth larval instar & $3.16 \pm 0.51$ & $67.3 \pm 10.9$ & $13.6 \pm 0.5$ \\
Fifth larval instar & $2.55 \pm 0.70$ & $139.9 \pm 21.8$ & $22.4 \pm 1.5$ \\
Sixth larval instar & $6.05 \pm 0.80$ & $548.1 \pm 73.5$ & $34.6 \pm 1.1$ \\
Pupea & $10.27 \pm 1.02$ & $217.2 \pm 37.1$ & $15.4 \pm 2.1$ \\
Adult & $11.83 \pm 0.38$ & $129.0 \pm 24.0$ & $18.0 \pm 1.2$ \\
\hline
\end{tabular}

Source: Cokola (2018).

moths of species of the genus Spodoptera (Cokola, 2018). This is the case of male adult of $S$. frugiperda which can be easily confused with those of Spodoptera ornithogalli and females, of Spodoptera exigua (Hardke et al., 2015). The genitalia of the males of S. ornithogalli are different from those of $S$. frugiperda - the double coremata lobe and the larger and wider clavus (Cokola, 2018). In S. frugiperda, the valve is also less wide and the female genitalia of $S$. exigua are different from those of $S$. frugiperda (par) by the elongated corpus bursae and signum (Hardke et al., 2015). Samples of entomological materials from several sources in West and Central Africa were sent for accurate diagnosis in the IITABenin station, where morphology the characters of immature stages and adult moths, including male and female genitalia were examined using keys for positive identification of $S$. frugiperda (Goergen et al., 2016). To confirm the identity of the species, present in Africa further, larval and adult specimens from Nigeria and São Tomé Et Príncipe were analysed by "DNA barcoding" at the Virology and Molecular Diagnostics Unit at IITA-Nigeria (Goergen et al., 2016).

\section{Ecology}

S. frugiperda is a tropical and subtropical species that adapts well to warm regions around the world (CABI, 2019). Temperature is a very important index for its growth and development (Cokola, 2019). The developmental time of eggs, larvae and pupae decreases with temperature up to $35^{\circ} \mathrm{C}$ (Hogg et al., 1982). Modelled data estimates made on temperature variations for growth and development of S. frugiperda are $12,25,30,39$ and $60^{\circ} \mathrm{C}$ for the base (minimum) temperature, lowest optimum temperature, highest optimum temperature, maximum temperature, as well as degree day, respectively (Du Plessis et al., 2018). Temperature minimum of $8.7^{\circ} \mathrm{C}$ and maximum of $39.8^{\circ} \mathrm{C}$ have been reported for the growth and development of $S$. frugiperda (Valdez-Torres et al., 2012). Similar temperatures were determined by López et al. (2019) with a minimum of 10.9 and $9.1^{\circ} \mathrm{C}$ days for the development of $S$. frugiperda with systematic mortality of all biological developmental stages of the pest at a temperature of $0^{\circ} \mathrm{C}$ (Luginbill, 1928). The fecundity and longevity of the adult insect are highest between 21 and $25^{\circ} \mathrm{C}$ (Barfield and Ashley, 1987). Rainfall, irrigation and colder annual temperatures are important variables with a direct negative effect on larval and pupal survival (Day et al., 2017).

\section{Damage and economic importance}

S. frugiperda was reported to be a destructive pest of many crops over 200 years ago (Luginbill, 1928). The larvae of S. frugiperda cause severe damage to all phenological stages of the plant. The caterpillar is capable of attacking 100 different plant species and 27 plant families with rapid oviposition and unimaginable proliferation, thus increasing the risks of a generalised infestation of different farms (Villa-Castoreña et al., 2004). With an unrivalled preference for maize (Day et al., 2017) which is a main staple food of the population in Sub-Saharan Africa (Ekpa et al., 2018), S. fruigiperda can also attack many other important crops viz sorghum, rice, sugarcane, cabbage, beet, groundnut, soybean, onion, pasture grasses, millet, tomato, crabapple and cotton (Prasanna et al., 2018). Yield losses of $15-73 \%$ are recorded when $55-100 \%$ of the plants are infested by $S$. frugiperda especially in the middle and late stages of maize development (Hruska and Gould, 1997). The larval stages of the pest appear to be much more damaging to maize in West and Central Africa than most other Spodopteran African species, as the larvae cause significant damage (Figure 5) on this economically important crop (Goergen et al., 2016). The responses of maize germplasm under fall armyworm infestation are measured on the Davis scale, which assesses the extent of leaf damage or ear damage compared to a susceptible control on a scale of 1 to 9 (Davis et al., 1992).

\section{Surveillance and early warning against $S$. frugiperda}

Due to its rapid spread and high capacity to cause widespread damage to several crops, the fall armyworm poses a serious threat to food and nutrition security and livelihoods of hundreds of millions of farming households in Sub-Saharan Africa (Prasanna et al., 2018). Early detection of the pest is therefore necessary through monitoring and early warning to assess accurately the level of fall armyworm infestation in the fields (Prasanna et al., 2018). Frequent observation and estimation of pest population and losses should be carried out in maize fields using suitable methods either by scouting, use of pheromone traps or light traps (Day et al., 2017). Insect captures indicate the presence of moths in the area, but may not be accurate indicators of density. Light traps can be used to monitor the adult fall armyworm, which traps both male and female insects. Monitoring is usually conducted to assess both the economic risk of pest infestation and the potential effectiveness of early and sustainable pest control interventions in fields or farms (Prasanna et al., 2019). This monitoring can be done by walking in a "W" pattern in the field with gaps of 4-5 outer rows between two points to be sampled (McGrath et al., 2018). The alert is triggered once $5 \%$ of the plant is damaged at the seedling stage (Kumbhar, 2019). Similarly, this alert should be triggered if 10 and $20 \%$ are damaged at the intermediate and late whorl stage respectively (Kumbhar, 2019). 


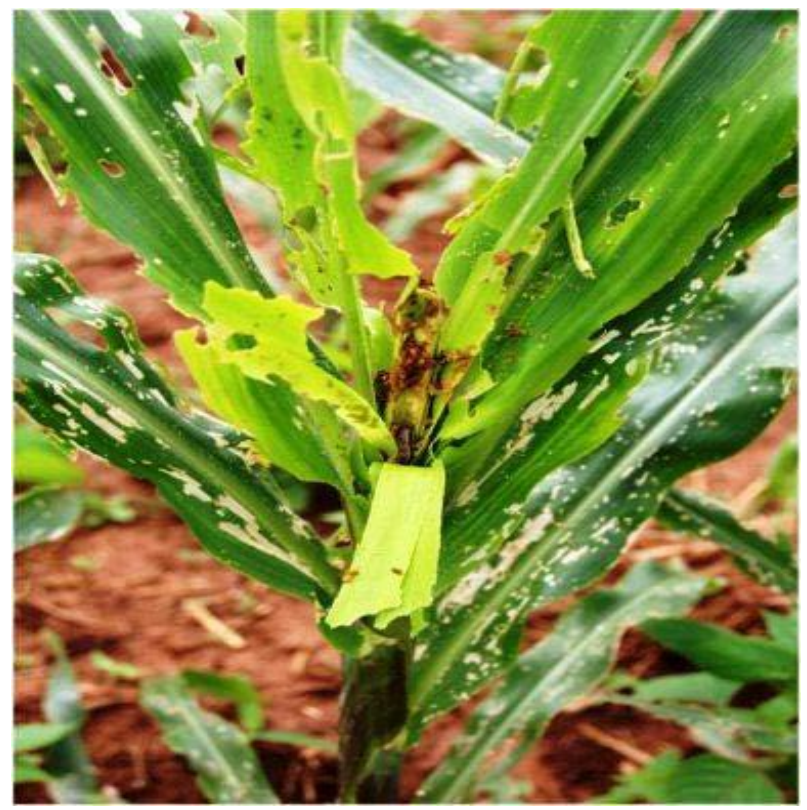

Figure 5. Damage of S. frugiperda on a maize plant in South Benin.

Source: Goergen (2016).

\section{Methods of control of S. frugiperda}

\section{Cultural and varietal control}

Cultural practices including crop association, conservation agriculture and its components generally improve biological activity within the cropping system while limiting insect and pathogen attacks. This approach provides shelter for predators and natural enemies of $S$. frugiperda and is a means of controlling the larvae of the pest by reducing its proliferation (Prasanna et al., 2019). A study conducted in Benin revealed that about 38\% of the farmers have used at least one agricultural practice for the control of $S$. frugiperda in maize fields (Houngbo et al., 2020). This study also concluded (based on assessment of farmers' perceptions) that the most common management method used by farmers was chemical control through the use of synthetic pesticides (91.4\%) while only $1.9 \%$ of botanical pesticides and $6.6 \%$ of other pest control practices were used. Information on farmers' knowledge and management practices is essential for developing appropriate management methods tailored to farmers' needs (Obopile et al., 2008).

Regarding varietal control, studies conducted in the United States at the Southern Insect Control Research Unit showed that $S$. frugiperda larvae fed on Bt maize hybrids expressing the Cry1Ab protein showed a decrease in weight within 5 days of observation (Anne-Marie, 2006). This weight decrease was significantly correlated with the amount of toxin present in the plant material consumed by the larvae (Anne-Marie, 2006) In the same area, laboratory trials were conducted to compare the behaviour of $S$. frugiperda larvae fed on transgenic and conventional maize plants (Bokonon-Ganta et al., 2003). Significant differences were observed in these trials between larvae fed on transgenic and conventional maize at several levels namely survival, weight and development time of larvae and pupal stage with larval survival rates of $28-70 \%$ on the two transgenic cultivars, compared to 62 $97 \%$ recorded on both the conventional cultivars and artificial diet (Bokonon-Ganta et al., 2003). Fall armyworm resistant germplasm has been developed in Mexico, USA and Brazil with a diversity of resistant varieties identified which indicated that there are many conventional traits to support a forward breeding strategy to incorporate fall armyworm resistance into the genetic elite of maize adapted to Africa (Prasanna et al., 2019). In some countries in Africa such as Cameroon, Egypt, Ghana, Kenya, Malawi, Nigeria, and Uganda, research has been conducted on resistant maize varieties that have yielded encouraging results in managing $S$. frugiperda but much work remains to be done (et al., 2018).

\section{Control based on the use of parasitoids and predators as natural enemies}

S. frugiperda has a diverse complex of natural enemies in the Americas and the Caribbean basin (Ashley, 1979; Ashley et al., 1982; Molina-Ochoa et al., 2003). In North and South America, studies revealed 53 species of parasitoids of S. frugiperda in 43 genera and 10 families, including Braconidae, Ichneumonidae and Tachinidae (Table 3), which accounted for 16,19 and $47 \%$ of the genera and 15, 17 and $53 \%$ of the species in this group respectively (Ashley, 1979). Subsequently, 150 species of parasitoids and parasites of $S$. frugiperda have been reported from the Americas and the Caribbean Basin, belonging to 14 families (Table 2), namely nine in the Hymenoptera, four in the Diptera and one nematode (Molina-Ochoa et al., 2003). Ten species of Hymenoptera belonging to five families including Telenomus remus, recognised as a parasitoid of $S$. frugiperda eggs were tested to control S. frugiperda (Cokola, 2018; Hoballah et al., 2004; Gutiérrez-Martínez et al., 2012). Chelonus insularis (Hymenoptera: Braconidae) and Cotesia arginiventris (Hymenoptera: Braconidae) were identified as a result of a survey as the main parasitoids of $S$. frugiperda eggs and larvae and cited as the most abundant in north of America (López et al., 2018). Braconidae were the best represented (Table 3) with 261 specimens $(21.75 \%$ of total parasitism), of which 257 were Chelonus insularis (21.42\%), 
Table 3. Spodoptera frugiperda's parasitoids and predators

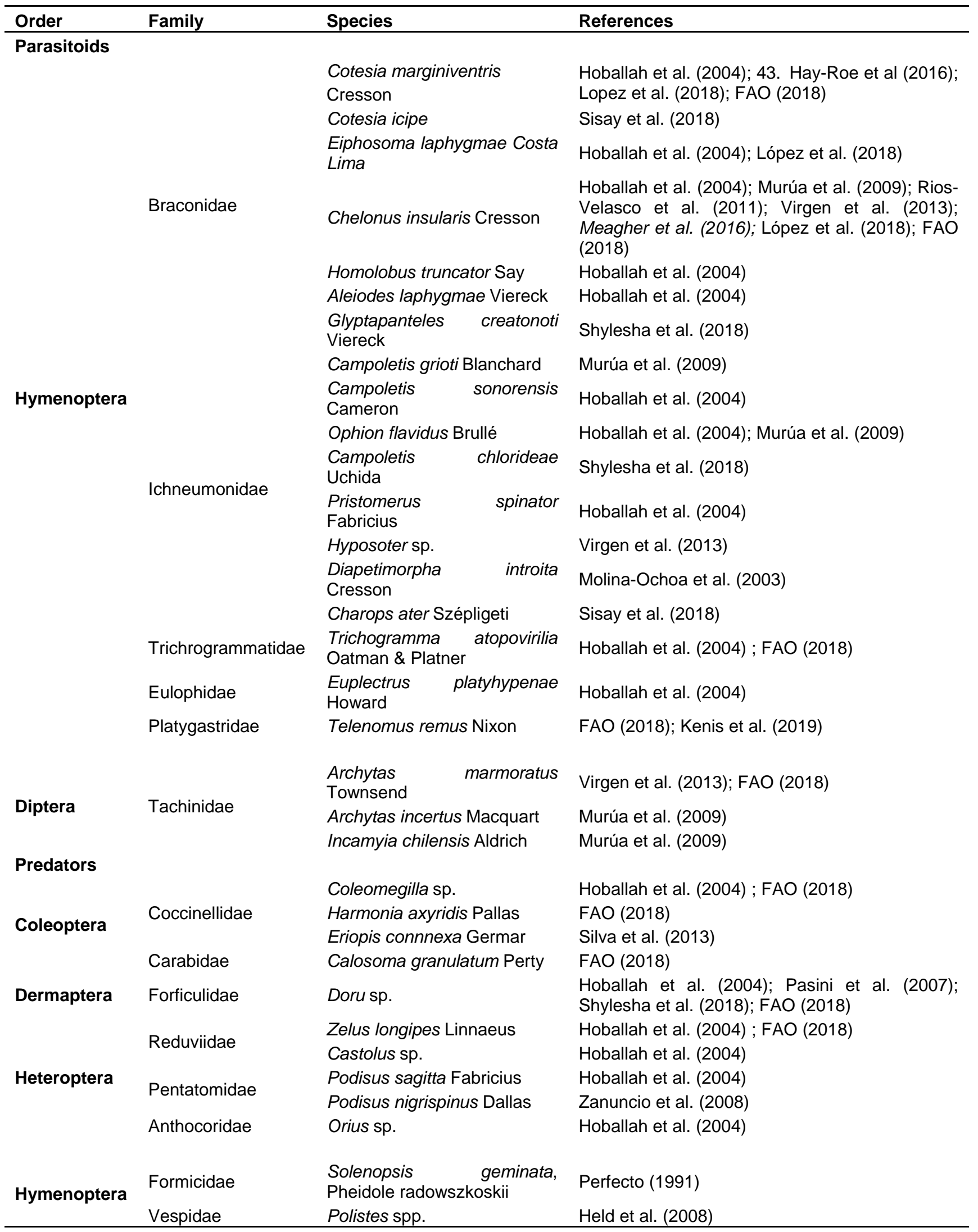

Source: Cokola (2018). 
Chelonus cautus (0.25\%) and C. sonorensis (0.08\%) (Cokola, 2018). Although T. remus was introduced to Brazil several decades ago, its natural occurrence in the fields has been very rare, while populations of $T$. pretiosum and/or $T$. atopovirilia are often reported (Beserra et al., 2002). Of these three species, T. remus has been considered the best candidate from augmentative biology, because of its ability to reach the inner layers of $S$. frugiperda egg masses (Cave, 2000). Laboratory studies have shown that $T$. remus parasitises $S$. frugiperda eggs more rapidly than $T$. pretiosum and, when the two species are brought together in an arena containing $S$. frugiperda eggs, the majority of emerged adults are of $T$. remus (Carneiro and Fernandes, 2012). However, there are no real studies exploring the interference and exploitation competition between $T$. remus, $T$. atoporivilia and $T$. pretiosum under field conditions but some work on natural enemy parasitoids of $S$. frugiperda in Africa has been carried out (Kenis et al., 2019).

A recent study on the first global modelling efforts by the fitted procedure of a machine learning algorithm to predict the habitat suitability of $S$. frugiperda and its major parasitoids namely Chelonus insularis, Cotesia marginiventris, Eiphosomala phygmae, Telenomus remus and Trichogramma pretiosum, to be considered for biological control was conducted (Tepa-Yotto et al., 2021). Modelled predictions showed establishment potentials of the five hymenopteran parasitoids of the pest in the coastal belt of West Africa from Côte d'Ivoire to Nigeria, the Congo Basin in East Africa, East Asia, Southeast and parts of Eastern Australia, and Western and Southern Europe which are areas heavily affected by the pest (Tepa-Yotto et al., 2021). Most reviews of parasitoids of $S$. frugiperda have focused on those that attack eggs and larvae (Ashley, 1986). However, there is a lack of information on the spatio-temporal distribution and determinants of better utilization of its local natural enemies in Sub-Saharan Africa. Forficulidae have been identified as important predators of $S$. frugiperda (Shylesha et al., 2018). Eriopis connnexaa has been identified as a potential predator for the control of S. frugiperda (Silva et al., 2013). Some species of Coccinellidae such as Harmonia axyridiscan also attack S. frugiperda (Dutra et al., 2012).

\section{Control based on the use of entomopathogenic fungi}

It is estimated that 750 to over 800 fungal species from more than 90 genera have been described as pathogens against different insect species (Samson and Popovic, 1988). However, only about a dozen of these entomopathogenic fungal species are available for pest management at the grower level (Hajek and St. Leger, 1994) and others are effective against a wide range of insect pests including Spodopteran species (Purwar and Sachan, 2005). For insect control, Beauveria bassiana is known to be the most common, highly effective and widespread entomopathogenic fungus worldwide (Khan and Ahmad, 2015). Ruiz-Nájera et al. (2013) isolated Nomurae arileyi from 38 larval corpses of $S$. frugiperda. Work revealed that the concentration of $1 \times 10^{8}$ conidia/ml was the most effective dose of entomopathogenic fungi (Kaur et al., 2009). Other studies in Faisalabad, Pakistan having investigated the efficacy of entomopathogenic fungi on Lepidoptera revealed that the susceptibility of insects subjected to the action of the said fungi decreases with an increase in the age of 285 larvae (Asi et al., 2013). The mortality of S. frugiperda was evaluated under laboratory conditions using various concentrations of conidia of a native strain and a commercial strain of $M$. anisopliae (RomeroArenas et al., 2014). The highest mortality that is, $72.5 \%$ was recorded in the indigenous strain while $32.5 \%$ was obtained in the commercial strain whose results revealed lower efficiency compared to the indigenous strain (Romero-Arenas et al., 2014). It has been reported that all species of lepidopteran pests of vegetable crops, were susceptible to $B$. bassiana while reporting that S. frugiperda was the least susceptible (Wraight et al., 2010).
Control using entomopathogenic bacteria, nematodes and viruses

Among the alternatives to control $S$. frugiperda, the use of Bacillus thuringensis (Bt) has been the subject of interest because of its effectiveness in controlling the pest and its low impact on natural enemies (Polanczyk and Alves, 2005). Studies have shown that $B t$ affects biological parameters with a definite influence on the weight of larvae, pupae, oviposition and fecundity of $S$. frugiperda females (Polanczyk and Alves, 2005). Bt Cry protein has been effectively used in America for the control of $S$. frugiperda but resistance of the pest against this protein has been noted (Farias et al., 2014; Dangal and Huang, 2015). The composition, abundance and diversity of microbiomes associated with larval and adult specimens of S. frugiperda have been studied in Africa (Gichuhi et al., 2020) however the first data on the efficacy of $B t$ for the control of $S$. frugiperda in Africa were provided by Botha et al. (2019). Entomopathogenic nematodes (EPNs) have been used as biological control agents to control some species of the genus Spodoptera in the laboratory and in the field (Campos-Herrera and Gutierrez, 2008). Nematodes, grouped in two main families Steinernematidae and Heterorhabditidae are obligate parasites of some insect species and more specifically S. frugiperda and are associated with some symbiotic bacteria (Sree and Varma, 2015). One species each of Steinernema and Heterorhabditis have been used for the control of $S$. frugiperda with an efficiency evaluated up to $100 \%$ of larval mortality (Andaló et al., 2010). Steinernema and Heterorhabditis have been used to control $S$. frugiperda in association with some insecticides (Negrisoli et al., 2013). S. frugiperda, is susceptible to several entomopathogens including a nuclear polyhedrosis virus (NPV) and a Granulosis virus (GV) (Gardner and Fuxa, 1980). Research on the use of viruses as entomopathogens is focused on baculoviruses (Sree and Varma, 2015). For the control of S. frugiperda, Nucleo Polyhedro Viruses (NPVs) have been the most studied (Berretta et al., 1998). The Nucleo Polyhedro Virus (NPV) of S. frugiperda (SfMNPV) has been isolated from populations of armyworms in North, Central and South America (Berretta et al., 1998; Shapiro et al., 1991). Some isolates of this virus have been evaluated in the field as potential biopesticides to control S. frugiperda on maize (Moscardi, 1999) resulting in high levels of larval mortality associated with significant mortality due to natural parasitism (Armenta et al., 2003; Castillejos et al., 2002). In southern Mexico, the impact of organophosphate insecticides (chlorpyrifos, methamidophos), carbamate (carbaryl) and pyrethroids (cypermethrin) commonly used in corn fields with natural enemies of crop pests has been compared to that of 'a nucleopolyhedron (Baculoviridae) of Spodoptera frugiperda. The results showed a mortality rate ranging from 75 to $90 \%$ of the natural enemies after the application of these synthetic insecticides while the bioinsecticide had not induced any effect. These synthetic insecticides were applied at the rates recommended on the product label using a hand-held backpack sprayer equipped with a cone nozzle. The biological pesticide was applied at the rate of $3 \times 10^{12}$ occlusions bodies (OB)/ha using identical equipment. The effects of pesticides on arthropods on corn plants were quantified at intervals of 1 to 22 days after application. The biological insecticide based on $S$. frugiperda nucleopolyhedrovirus had no adverse effect on natural enemies of insects or other non-target insect populations. Applications of carbamate, pyrethroid and organophosphate insecticides all reduced the abundance of natural enemy insects, but for a relatively short period (8-15 days) (Martinez et al., 2003).

\section{Use of plant extracts}

To limit environmental and health risks, the use of less toxic natural products, such as neem, pyroligneous and asteraceous extracts, is a sustainable alternative in agricultural areas (Charleston et al., 
2005). In Brazil, experiments carried out at $\left(25 \pm 1^{\circ} \mathrm{C}\right)$ with a $12 \mathrm{~h}$ photoperiod and $(70 \pm 10 \%)$ relative humidity in the laboratory using aqueous extracts of neem and pyroligneous diluted in water (10 or $20 \mathrm{ml} / \mathrm{L}$ ) and applied to freshly laid eggs of $S$. frugiperda or to day old and two-days-old eggs resulted in a reduction in their hatching rate (Tavares et al., 2009). In Ethiopia, high mortality of $S$. frugiperda was reported with extracts of Jatropha curcas, Militia ferruginea, Phytolacca dodecandra, Scinus molle, Melia abyssinica, Nicotiana tabacum, Lantana camara, Chenopodiumam broides, Azadirachta indica, and Jatropha gossypifolia (Sisay et al., 2019). Similar activities have been reported for $A$. indica and N. tabacum against $S$. frugiperda in Africa (Phambala et al., 2020). The most promising plant species in Africa due to their low toxicity, abundance and bioactivity against $S$. frugipera are Lippia javanica, Ocimum basilicum and Cymbopogon citratus which have shown various activities including decreased feeding and reproduction as well as increased mortality of the pest (Silva et al., 2013). Trials conducted under laboratory conditions on the bioactivity of plant extracts of Calotropisprocera, Jatropha curcas, Cymbopogon nardus, Zyzyphus joazeiro, Morinda citrofolia, and Magonia pubescamens generated interest in the use of their extracts because, having resulted in an increase in larval mortality and a significant decrease in the weight of $S$. frugiperda pulps (Santos et al., 2012). The results of this study showed that methanolic extracts of leaves and fruit peels, applied on $S$. frugiperda at the $2^{\text {nd }}$ larval stage fed on artificial diet resulted in reduced larval growth, longer developmental time, reduced fertility as well as increased mortality of the pest (Santos et al., 2012). The T. saponaria extract was the most promising for the control of $S$. frugiperda, possibly because its seeds were rich in fat, yielding an equally fatty extract with adjuvant capacity thus facilitating the attachment and distribution of the extract on maize leaves, thereby increasing the insecticidal action (Santos et al., 2012). However, it remains to be determined which insecticidal compounds in these plants could lead to new natural insecticidal products that could be developed (Alves et al., 2012). This provides an opportunity for exploration and research of other plants with these compounds to incorporate them into the pool of plants that provide promising results for the management of $S$. frugiperda in Africa (Santos et al., 2012).

\section{Chemical control methods and risks of pest resistance to molecules}

Insecticidal control of $S$. frugiperda is often necessary in order to protect the crops and ensure adequate productivity (Luginbill, 1928; Straub and Hogan, 1974). The techniques used in this case are dictated by the developmental stage and growth characteristics of the host crop as well as the available insecticide application methods (Togola et al., 2018). Management of the pest requires the use of large quantities of insecticides and sometimes the use of several types and formulations of chemicals, with high environmental and health risks incurred by both producers and consumers (Togola et al., 2018). Effective application of pesticides may result in some reduction of pests, but also cause damage to beneficial insect populations thus increasing pest population pressure and crop damage (Prasanna et al., 2018).

Results of trials conducted in Mokwa, Nigeria revealed the presence of five insecticidal compounds (cypermethrin, deltamethrin, lambda-cyhalothrin, permethrin and chorpyrifos) in soil samples with possible negative effects on soil dwelling organisms and other non-target species (Togola et al., 2018). This was also detrimental to the environment, as the molecules of the products used to affect local biodiversity, environmental components, human health and pest resistance to the molecules used (Sellami et al., 2015). A strain of S. frugiperda, collected from a cornfield in northern Florida showed resistance to commonly used insecticides. Resistance to pyrethroids ranged from 2 to 216-fold; resistance to organophosphate insecticides ranged from 12 to 271fold and resistance to carbamates ranged from 14 to 192-fold (Yu, 1991). The highest level of resistance was observed with carbary (Yu, 1991).

\section{Issues related to the integrated management of S. frugiperda}

The limitations associated with the use of synthetic plant protection products with their numerous risks to human health, the imbalance of environmental components and pest resistance (Barzman et al., 2015) impose the adoption of agroecological practices and integrated management of $S$. frugiperda as an unquestionable option in view of the speed of the pest's progression and the damage it causes to farmers (Georgen, 2016; Hay-Roe et al., 2016). The preferred management option for $S$. frugiperda is therefore Integrated Pest Management (IPM-Integrated Pest Management), based on the use of a combination of control methods that is sustainable, cost-effective and results in minimal risks to humans and the environment (Day et al., 2017).

\section{Conclusions}

The present literature review has provided an overview of updated state-of-the-art on S. frugiperda bioecology and management Information related to taxonomy, description, ecology, origin, damage, economic importance, dispersal of the pest and its management by agricultural chemicals is available. Similarly, a sufficient range of scientific evidence on the existence and use of natural enemies, entomopathogens and plant extracts is available. However, the literature reveals little empirical evidence to guide recommendations for effective control of S. frugiperda in Africa since existing work has not addressed, in a strict sense, control methods based on integrated pest management in the African context, even though this approach represents an important sustainable alternative beneficial to vulnerable small holder farmers.

\section{LIMITATIONS AND PROSPECTS}

The alternative methods to synthetic chemical inputs each have their advantages, but also some limitations. A combination of several much more integrated approaches is therefore needed to control S. frugiperda sustainably. The variability of the insect's susceptibility to the products used and the adverse effects of the latter on human health and the environment should imply a more specific control considering the pedoclimatic and socioeconomic conditions of the farmers. In this control in an African context where most farmers are vulnerable and uneducated, it is imperative to consider the sustainability of the choices made on the technical and operational levels. It is with this perspective that we will start work on the evaluation of the oviposition performance of key parasitoids of $S$. frugiperda and on entomopathogens of African strains in order to contribute to the integrated management of the pest. Similarly, some methods based on the valorisation of insecticidal plants and on empirical 
practices still in use and demonstrating their efficacy should also be tested in order to establish the scientific basis of their real efficacy on pest control and on their safe use and minimal impacts on human and environment health.

\section{CONFLICT OF INTERESTS}

The authors have not declared any conflict of interests.

\section{REFERENCES}

Alves DS, Carvalho GA, Oliveira DF, Sâmia RR, Villas-Boas MA (2012). Toxicity of copaiba extracts to armyworm (Spodoptera frugiperda). African Journal of Biotechnology 11(24):6578-6591.

Andaló V, Santos V, Moreira GF, Moreira CC, Junior AM (2010). Evaluation of entomopathogenic nematodes under laboratory and greenhouses conditions for the control of Spodoptera frugiperda. Ciência Rural, Santa Maria 40(9):1860-1866.

Ashley TR (1979). Fall Armyworm Symposium: Classification and Distribution of Fall Armyworm Parasites. Florida Entomologist 62(2):114-123.

Ashley TR (1986). Geographical distributions and parasitization levels for parasitoids of the fall armyworm, Spodoptera frugiperda. Florida Entomologist 69(3):516-524.

Ashley TR, Waddill VH, Mitchell ER, Rye J (1982). Impact of native parasites of the fall armyworm, Spodoptera frugiperda (Lepidoptera: Noctuidae), in South Florida and release of the exotic parasite, Eiphosomavitticole (Hymenoptera: Ichneumonidae). Environmental Entomology 11(4):833-837.

Asi MR, Bashir MH, Afzal M, Zia K, Akram M (2013). Potential of entomopathogenic fungi for biocontrol of Spodoptera litura fabricius (lepidoptera: noctuidae). The Journal of Animal and Plant Sciences 23(3):913-918.

Barfield S, Ashley TR (1987). Effects of Corn Phenology and Temperature on the Life Cycle of the Fall Armyworm, Spodoptera frugiperda (Lepidoptera: Noctuidae). The Florida Entomologist 70(1):110-116.

Baudron F, Zamah-Allah M, Chaipa I, Chari N, Chinwada P (2019). Understanding the factors influencing fall armyworm (Spodoptera frugiperda J.E. Smith) damage in African smallholder maize fields and quantifying its impact on yield. A case study in Eastern Zimbabwe. Crop Protection 120:141-150

Berretta MF, Rios ML, Sciocco de Cap A (1998). Characterization of a Nuclear Polyhedrosis Virus of Spodoptera frugiperda from Argentina. Journal of Invertebrate Pathology 71(3):280-282.

Beserra EB, Dias CTDS, Parra JRP (2002). Distribution and natural parasitism of Spodoptera frugiperda (lepidoptera: noctuidae) eggs at different phenological stages of corn. Florida Entomologist 85(4):588593.

Bokonon-Ganta A, Bernal JS, Pietrantonio PV, Sétamou M (2003). Survivorship and development of fall armyworm, Spodoptera frugiperda (J. E. Smith) (Lepidoptera: Noctuidae), on conventional and transgenic maize cultivars expressing Bacillus thuringiensis Cry9C and Cry $1 \mathrm{~A}(\mathrm{~b})$ endotoxins. International Journal of Pest Management 49(2):169-175.

Botha AS, Erasmus A, du Plessis H, Van den Berg J (2019). Efficacy of Bt Maize for Control of Spodoptera frugiperda (Lepidoptera: Noctuidae) in South Africa. Journal of Economic Entomology 112(3):1260-1266. https://doi.org/10.1093/jee/toz048

Busato GR, Grützmacher AD, Garcia MS, Giolo FP, Zotti MJ, Stefanello Júnior JJ (2005). Biologia Comparada de Populações de Spodoptera frugiperda (J.E. Smith) (Lepidoptera: Noctuidae) em Folhas de Milho e Arroz. Neotropical Entomology 34(5):743-750.

CABI (2019). Invasive Species Compendium Spodoptera frugiperda (fall armyworm). Detailed coverage of invasive species threatening livelihoods and the environment worldwide https://www.cabi.org/isc/datasheet/29810 consulté le 4 janvier 2021 à 12h50'

Campos-Herrera R, Gutierrez C (2008). Screening Spanish isolates of steinernematid nematodes for use as biological control agents through laboratory and greenhouse microcosm studies. Journal of Invertebrate Pathology 100(2):100-105.

Capinera JL (2001). Handbook of Vegetable Pests. Academic Press, San Diego 729 p.

Capinera JL (2014). Fall Armyworm, Spodoptera frugiperda (JE Smith) (Insecta: Lepidoptera: Noctuidae). Florida (FL): US Department of Agriculture, UF/IFAS Extension Service, University of Florida; [accessed 2017Sept 05]. https://journals.flvc.org

Carneiro TR, Fernandes OA (2012). Interspecific interaction betweenTelenomus remus (Hymenoptera: Platygastridae) and Trichogramma pretiosum (Hymenoptera: Trichogrammatidae) on Spodoptera frugiperda (Lepidoptera: Noctuidae) eggs. Anais da Academia Brasileira de Ciências 84(4):1127-1135.

Castillejos V, Trujillo J, Ortega LD, Santizo JA (2002). Granular phagostimulant nucleopolyhedrovirus formulations for control of Spodoptera frugiperda in maize. Biological Control 24(3):300-310.

Castoreña V, Magdalena M, Valencia C, Alonso E (2004). Determination of larval stages of Spodoptera frugiperda (J. E. Smith) (Lepidoptera: Noctuidae) for the construction of a prediction model. Folia Entomológica Mexicana 43:307-312 Sociedad Mexicana de Entomología, A.C. Xalapa, Mexico

Cave RD (2000). Biology, ecology and use in pest management of Telenomusremu. Biocontro/News and Information 21(1):21N-26N.

Charleston DS, Kfir R, Dicke M, Vet LEM (2005). Impact of botanical pesticides derived from Melia azedarach and Azadirachta indica on the biology of two parasitoid species of the diamondback moth. Biological Control 33(2):131-142.

Thierfelder C, Niassy S, Midega C, Sevgan S, van den Berg J, Prasanna BM, Baudron F, Harrison R, (2018). Low-Cost Agronomic practices and Landscape Management Approches to Control FAW.CIMMYT, Mexico CDMX (2018), pp. 89-96.

Cock JWM, Beseh PK, Buddie AG, Cafa G, Crozier J (2017). Molecular methods to detect Spodoptera frugiperda in Ghana, and implications for monitoring the spread of invasive species in developing countries. Scientific Reports 7:4103 | DOI:10.1038/s41598-017-04238-y 10.

Cokola MC (2018). Monitoring, molecular characterization and biological control of Spodoptera frugiperda (Lepidoptera: Noctuidae). Master of specialization in integrated production and preservation of natural resources in urban and peri-urban environment, Gembloux Agro-Bio Tech (GXABT), P 93. CURI/URL: http://hdl.handle.net/2268.2/8077

Da Sylva ACB, Sardi JO, de Oliveira DGL, de Oliveira CFR, dos Santos HF, dos Santos EL (2016). Development of a novel anti-biofilm peptide derived from profilin of Spodoptera frugiperda. Biofouling 36(5):516-527.

Dangal V, Huang F (2015). Costs of Cry1F resistance in two populations of fall armyworm, Spodoptera frugiperda (J.E. Smith), collected from Puerto Rico and Florida. Journal of Invertebrate Pathology 127:81-86.

Davis FM, Seong NG, Williams WP (1992). Visual rating scales for screening whorl-stage corn for resistance to fall armyworms. Technical bulletin (Mississippi Agricultural and Forestry Experiment Station) 186:1-9.

Day R, Abrahams P, Phil A, Bateman M, Beale T, Clottey V, Cock M, Colmenarez Y, Corniani N, Early R, Godwin J, Gomez J, Moreno PG, Murphy ST, Oppong-Mensah B, Phiri N, Pratt C, Silvestri S, Witt A (2017). Fall Armyworm: Impacts and Implications for Africa. Outlooks on Pest Management 28(5):196-201.

Du Plessis H, Schlemmer ML, Van den Berg J (2020). The Effect of Temperature on the Development of Spodoptera frugiperda (Lepidoptera: Noctuidae). Insects 11(4):228.

Dutra CC, Koch RL, Burkness EC, Meissle M, Romeis J, Hutchison WD, Fernandes MG (2012). Harmonia axyridis (Coleoptera: Coccinellidae) Exhibits No Preference between Bt and Non Bt Maize Fed Spodoptera frugiperda (Lepidoptera: Noctuidae). PLoS One 7(9):e44867. https://doi.org/10.1371/journal.pone.0044867

Ekpa O, Palacios-Rojas N, Kruseman G, Fogliano V, Linnemann AR (2018). Sub-Saharan African maize-based foods: Technological 
perspectives to increase the food and nutrition security impacts of maize breeding programs. Global Food Security 17:48-56. https://doi.org/10.1016/j.gfs.2018.03.007

Fan J, Wu P, Tian T, Ren Q, Haseeb M, Zang R (2020). Potential Distribution and Niche Diferentiation of Spodoptera frugiperda in Africa. Insects 11(6):383. https://doi.org/10.3390/insects11060383

Farias JR, Andow DA., Horikoshi RJ, Sorgatto RJ, dos Santos AC, Omoto C (2014). Field-evolved resistance to Cry1F maize by Spodoptera frugiperda (Lepidoptera: Noctuidae) in Brazil. https://doi.org/10.1016/j.cropro.2014.06.019

Food and Agriculture Organization of the United Nations (FAO) (2018). Integrated management of the fall armyworm on maize: a guide for farmer field schools in Africa $118 p$

Gardner WA, Fuxa JR (1980). Pathogens for the Suppression of the Fall Armyworm DOI 519 10.2307/3494527

Gichuhi J, Sevgan S, Khamis F, Van den Berg J, du Plessis H, Ekesi S, Herren JK (2020). Diversity of fall armyworm, Spodoptera frugiperda and their gut bacterial community in Kenya. PeerJ 8:e8701 https://doi.org/10.7717/peerj.8701

Goergen G, Kumar PL, Sankung SB, Togola A, Tamò M (2016). First Report of Outbreaks of the Fall Armyworm Spodoptera frugiperda (J E Smith) (Lepidoptera, Noctuidae), a New Alien Invasive Pest in West and Central Africa. PLoS One 11(10):e0165632. doi:10.1371/journal. pone.0165632

Gutiérrez-Martínez A, Tolon-Becerra A, Lastra-Bravo XB (2012). Biological control of spodoptera frugiperda eggs using Telenomus remus Nixon in maize-bean-squash polyculture. American Journal of Agricultural and Biological Sciences 7(3)285-292

Hajek AE, Leger RJ (1994). Interactions between fungal pathogens and insect hosts. Boyce Thompson Institute for Plant Research, Ithaca, New York pp. 14853-1801.

Hardke JT, Gus M Lorenz GM, Rogers Leonard B (2015). Fall Armyworm (Lepidoptera: Noctuidae) Ecology in Southeastern Cotton. Journal of Integrated Pest Management 6(1):10, https://doi.org/10.1093/jipm/pmv009

Hay-Roe MM, Meagher RL, Nagoshi RN, Newman Y (2016). Distributional patterns of fall armyworm parasitoids in a corn field and a pasture field in Florida. https://doi.org/10.1016/j.biocontrol.2016.02.003

Hoballah ME (2004). Occurrence and direct control potential of parasitoids and predators of the fall armyworm (Lepidoptera: Noctuidae) on maize in the subtropical lowlands of Mexico. https://doi.org/10.1111/j.1461-9555.2004.00207.x

Hogg DB, Pitre HN, Anderson RE (1982). Assessment of Early-Season Phenology of the Fall Armyworm (Lepidoptera: Noctuidae) in Mississippi. Environmental Entomology 11(3):705-710. https://doi.org/10.1093/ee/11.3.705

Houngbo S, Zannou A, Aoudji A, Sossou HC, Sinzogan A, Sikirou R, Zossou E, Vodounon HST, Adomou A, Ahanchédé A (2020). Farmers' Knowledge and Management Practices of Fall Armyworm, Spodoptera frugiperda (J.E. Smith) in Benin, West Africa. Agriculture 10(10):43. https://doi.org/10.3390/agriculture10100430

Hruska AJ, Gould F (1997). Fall Armyworm (Lepidoptera: Noctuidae) and Diatrae alineolata (Lepidoptera: Pyralidae): Impact of Larval Population Level and Temporal Occurrence on Maize Yield in Nicaragua. Journal of Economic Entomology 90(2):611-622. https://sci- hub.se/https://doi.org/10.1093/jee/90.2.611 p. 21

Kaur A, Singh NN, Mukesh K (2009). Screening of insecticides against egg parasitoid Trichogramma brasiliensis Ashmead (Hymenoptera: Trichogrammatidae). Indian Journal of Entomology 71(3):244-248.

Kenis $M$, du Plessis $H$, Van den Berg J, Niango Ba M, Goergen G, Kwadjo KE, Baoua B, Tefera T, Buddie A, Cafà G, Offord L, Rwomushana I, Polaszek A (2019). Telenomus Remus, a Candidate Parasitoid for the Biological Control of Spodoptera Frugiperda in Africa, is already Present on the Continent. Insects 10(4):92. https://doi.org/10.3390/insects10040092

Khan A, Ahmad W (2015). The Management of Spodopteran Pests Using Fungal Pathogens. Biocontrol of Lepidopteran Pests pp. 123160.

Kouakou M, Kobenan KC, Didi RJG, Bini KKN, Ochou Ochou G (2019). Detection of the Fall Armyworm, Spodoptera frugiperda (J. E. Smith, 1797) (Coleoptera: Noctuidae) and First Observations on its Biology in Côte d'Ivoire. European Scientific Journal April 2019 edition Vol.15, No.12 ISSN: 1857 -7881 (Print) e -ISSN 1857-566 7431. French

Kumbhar RA (2019). Current Status and Management of Fall Armyworm in India. Research Gate.

Kumela T, Simiyu J, Sisay B, Likhayo P, Mendesil E, Gohol L, Tefera T (2018). Farmers knowledge perceptions, and management practices of the new invasive pests, fall armyworm (Spodoptera frugiperda) in Ethiopia and kenya. January 2018 International Journal of Pest Management 65(1):1-9. DOI: 10.1080/09670874.2017.1423129

López MA, Martínez-Castillo AM, García-Gutiérrez C, Cortez-Mondaca E, Escobedo-Bonilla CM (2018). Parasitoids and Entomopathogens Associated with Fall Armyworm, Spodoptera frugiperda, in Northern Sinaloa. Southwestern Entomologist 43(4):867-881. http://www.bioone.org/doi/full/10.3958/059.043.0405

Luginbill P (1928). The Fall Armyworm. USDA Technical Bulletin N ${ }^{\circ} 34$. $91 \mathrm{p}$.

Barzman $M$, Bàrberi $P$, Birch ANE, Boonekamp $P$, Dachbrodt-Saaydeh S, Graf B, Hommel B, Jensen JE, Kiss J, Kudsk P, Lamichhane JR, Messéan A, Moonen AC, Ratnadass A, Ricci P, Sarah JL, Sattin M (2015). Eight principles of integrated pest management. Agronomy for Sustainable Development 35(4):1199-1215.

Armenta R, Martinez AM, Chapman JW, Magallanes R, Goulson D, Caballero P, Cave RD, Cisneros J, Valle J, Castillejos V, Penagos DI (2003). Impact of a nucleopolyhedrovirus bioinsecticide and selected synthetic insecticides on the abundance of insect natural enemies on maize in southern Mexico. Journal of Economic Entomology 96(3):649-661. https://doi.org/10.1093/jee/96.3.

McGrath D, Huesing J, Beiriger E, Nuessly RG, Tepa-Yotto TG, Hodson D, Kimathi E, Felege E, Abah Obaje J, Mulaa, M, Mendes AP (2018). Monitoring, Surveillance, and Scouting for Fall Armyworm, in: Prasanna, B.M., Huesing, J.E., Eddy, R., Peschke, V.M. (Eds.), Fall Armyworm in Africa: A Guide for Integrated Pest Management. Mexico, CDMX, 11-28.

Molina-Ochoa J, Carpenter JE, Einrichs EA, Foster JE (2003). Parasitoids and parasites of Spodoptera frugiperda (lepidoptera: noctuidae) in the americas and caribbean basin: an inventory. Florida Entomologist 86(3):22

Moscardi F (1999). Assessment of the application of baculoviruses for control of lepidoptera. Annual Review of Entomology 44(1):257-289.

Murúa MG, Molina-Ochoa J, Fidalgo P (2009). Natural distribution of parasitoids of larvae of the fall armyworm, Spodoptera frugiperda, in Argentina. Journal of Insect Science 9(1):20. https://academic.oup.com/jinsectscience/article/9/1/20/891778?login= true

Negrisoli CRCB, Negrisoli AS, Botton M, Garcia MS, Bernardi D (2013). Evaluation of efficacy of 18 strains of entomopathogenic nematodes (Rhabditida) against Planococcus citri (Risso, 1813) (Hemiptera: Pseudococcidae) under laboratory conditions. Experimental Parasitology 134(3):295-298.

Obopile M, Munthali DC, Matilo B (2008). Farmers' knowledge, perceptions and management of vegetable pests and diseases in Botswana. https://doi.org/10.1016/j.cropro.2008.03.003

Pasini A, Parra JRP, Lopes JM (2007). Dieta Artificial para Criação de Doru luteipes (Scudder) (Dermaptera: Forficulidae), Predator da Lagarta-do-Cartucho do Milho, 70 Spodoptera frugiperda (J.E. Smith) (Lepidoptera: Noctuidae), Neotropical Entomology 36(2):308-311.

Perfecto I (1991). Ants (Hymenoptera: Formicidae) as Natural Control Agents of Pests in Irrigated Maize in Nicaragua. Journal of Economic Entomology 84:65-70.

Phambala K, Tembo Y, Kasambala T, Kabambe VH, Stevenson PC Belmain SR (2020). Bioactivity of Common Pesticidal Plants on Fall Armyworm Larvae (Spodoptera frugiperda). Plants 9(1):112. https://doi.org/10.3390/plants9010112

Polanczyk RA, Alves SB (2005). Biological parameters of Spodoptera frugiperda (J.E. Smith) (Lepidoptera: Noctuidae) assayed with Bacillus thuringiensis berliner. Scientia Agricola 62:464-468. https://doi.org/10.1590/S0103-90162005000500009

Prasanna BM, Huesing J, Eddy R, Virginia R (2019). Fall Armyworm in frica, A guide for integrated Pest Management. Mexico: USAID and CIMMYT.

https://repository.cimmyt.org/xmlui/bitstream/handle/10883/19204/59 133.pdf 
Prasanna BM, Huesing JE, Eddy R, Peschke VM (2018). Fall armyworm in Africa: A guide to integrated pest management, First Edition.Mexico City, CDMX: CIMMYT. https://repository.cimmyt.org/xmlui/bitstream/handle/10883/19204/59 133.pdf

Purwar JP, Sachan GC (2005). Synergistic effect of entomogenous fungi on some insecticides against Bihar hairy caterpillar Spilarctiaobliqua (Lepidoptera: Arctiidae). Microbiological Research 161(1):38-42.

Romero-Arenas O, Rivera A, Aragon A, Parraguirre C, Cabrera E, Lopez F (2014). Mortality Evaluation of Armyworm (Spodoptera frugiperda J. E. Smith) by using Metarhiziumanisopliae In vitro. Journal of Pure \& Applied Microbiology 8(2):59-67

Rwomushana I, Bateman M, Beale T. Beseh P (2018). Fallarmyworm: impacts and implications for Africa: Evidence Note Update, https://www.researchgate.net/publication/328687643

Samson G, Popovic R (1988). Use of algal fluorescence for determination of phytotoxicity of heavy metals and pesticides as environmental pollutants. Ecotoxicology and Environmental Safety 16(3):272-278. https://doi.org/10.1016/0147-608 6513(88)90056-5

Santos BA, Giustolin TA, Alvarenga CD, Sousa MDC (2012). Seleção de espécies vegetais com potencialinseticida para o controle de Spodoptera frugiperda (J. E. Smith). In: XXIV Congresso Brasileiro de Entomologia, Curitiba, PR. Anais P 23.

Schmidt-Durán A, Villalba-Velásquez V, Chacón-Cerdas R, Martínez K, Flores-Mora D (2015). Larval stage prediction model of Spodoptera frugiperda collected in fig (Ficus carica) and discovery of Apanteles sp. as its parasitoid. Tecnología en Marcha 28(1):47-58.

Sellami S, Mesrati A, Tounsi S, Jamoussi K (2015). Toxicity, activation process, and histopathological effect of Bacillus thuringiensis vegetative insecticidal protein Vip3Aa16 on Tutaabsoluta. Applied Biochemistry and Biotechnology 175:1992-1999.

Shapiro DI, Fuxa JR, Braymer HD, Pashley DP (1991). DNA restriction polymorphismin wild isolates of Spodoptera frugiperda nuclear polyhedrosis virus. Journal of Invertebrate Pathology 58(1):96-105.

Kalleshwaraswamy CM, Maruthi MS, Pavithra HB (2018). Biology of invasive fall army worm Spodoptera frugiperda (JE Smith)(Lepidoptera: Noctuidae) on maize. Indian Journal of Entomology 80(3):540-543.

Shylesha AN, Jalali SK, Gupta A, Varshney R, Venkatesan T, Shetty P, Ojha R, Ganiger PC, Navik O, Subaharan K, Bakthavatsalam N (2018). Studies on new invasive pest Spodoptera frugiperda (JE Smith)(Lepidoptera: Noctuidae) and its natural enemies. Journal of Biological Control 32(3):145-51. DOI: 10.18311/jbc/2018/21707

Silva RB, Cruz I, Zanuncio JC, Figueiredo MC, Zanuncio TV, Serrão JE (2013). Spodoptera frugiperda (J.E. Smith) (Lepidoptera: Noctuidae) eggs as alternative food for rearing of lady beetles Eriopisconnexa (Germar) (Coleoptera: Coccinellidae). Biological Control 64(2):101105.

Sisay B, Tefera T, Wakgari M, Mendesil E (2019). The Efficacy of Selected Synthetic Insecticides and Botanicals against Fall Armyworm, Spodoptera frugiperda, in Maize. Insects 10(2):45. https://doi.org/10.3390/insects10020045

Sree KS, Varma A (2015). Biocontrol of Lepidopteran Pests. Switzerland: Springer International Publishing https://doi.org/10.1007/978-3-319-14499-3

Straub RW, Hogan HJ (1974). Feasibility of fall armyworm, Spodoptera frugiperda (Smith) control on late-planted dent corn. Food and Life Sciences Bulletin 49.

Tambo JA, Day RK, Lamontagne-Godwin J, Silvestri S, Beseh PK, Oppong-Mesah B, Phiri NA, Matimelo M (2020). Tackling fall armyworm (Spodoptera frugiperda) outbreak in Africa: an analysis of farmers' control actions. International Journal of Pest Management 66:4.

Tavares W de S, Cruz I, Petacci F, Lourenc S, Júnior o de A, Tavaresa WS, Cruza I, Petacci F, Louren S, Júnior A, Freitas SS, Zanuncio JC, Serrão JE (2009). Potential use of Asteraceae extracts to control Spodoptera frugiperda (Lepidoptera: Noctuidae) and selectivity to their parasitoids Trichogramma pretiosum (Hymenoptera: Trichogrammatidae) and Telenomus remus (Hymenoptera: Scelionidae). Industrial Crops and Products 30(3):384-388.
Tepa-Yotto GT, Tonnang HEZ, Goergen G, Subramanian S, Emily Kimathi E, Abdel-Rahman EM, Flo D, Thunes KH, Fiaboe KKM, Niassy S, Bruce A, Mohamed SA, Tamò M, Ekesi S, Sæthre MG (2021). Global Habitat Suitability of Spodoptera frugiperda (JE Smith) (Lepidoptera, Noctuidae): Key Parasitoids Considered for Its Biological Control. Insects 12(4):273.

Togola A, Meseka S, Menkir A, Badu-Apraku B, Boukar O, Tamo M, Djouaka R (2018). Measurement of Pesticide Residues from ChemicalControl of the Invasive Spodoptera frugiperda (Lepidoptera: Noctuidae) in a Maize Experimental Field in Mokwa, Nigeria. International Journal of Environmental Research and Public Health 15(5):849.

Valdez-torres JB, Soto-Landeros F, Osuna-Enciso T, Baez-Sanudo MA (2012). Phenological prediction models for white corn (Zea mays L.) and fall armyworms (Spodoptera frugiperda J.E. Smith). Agrociencia (Montecillo) 46(4):399-410.

Visser D (2017). Fall armyworm: an identification guide in relation to other common caterpillars, a South African perspective. Agricultural Research Council - Vegetable and Ornamental Plants. Identification guides $26 \mathrm{p}$.

Wraight SP, Ramos ME, Avery PB, Jaronski ST, Vandenberg JD (2010). Comparative virulence of Beauveria bassiana isolates against lepidopteran pests of vegetable crops. Journal of Invertebrate Pathology 103(3):186-199 https://doi.org/10.1016/j.jip.2010.01.001 